\title{
Code Mixing Used in the Utterances of Arab Descent Students in Surakarta, Indonesia (Sociolinguistics Study)
}

\author{
Hesti Indah Mifta NUR'AINI', St Y SLAMET'2, Budhi SETIAWAN ${ }^{3}$
}

\begin{tabular}{l} 
ARTICLE INFO \\
\hline Article History: \\
Received 01.09.2018 \\
Received in revised form \\
29.10 .2018 \\
Accepted \\
Available online 01.01 .2019
\end{tabular}

ABSTRACT

Arab descent students in Surakarta Indonesia are bilingual society. Bilingual society or multiling ual often insert several other language vocabulary in their daily communication, thus code-mixing occurred. This study aims to describe the form of code mixing in speech language used by students of Arab descent in the realm of education and its contributing factors. This research employed descriptive qualitative method. The data of the research was Arab descent students' utterances in Diponegoro Islamic High School, Surakarta. The utterances could be in the form of conversation among students and between teachers and students. The techniques of data collection were competent involvement techniques, recording techniques, and note-taking techniques. The technique of data analysis in this study used a matching technique. The technique of data validity was member checking to the participants in order to valid the data. Based on the results of data analysis which consist of seven utterances showed that code mixing occurred in word and phrase from Jav anese, Arabic, English into Indonesian Language. This is influenced by several factors including language majority, speech partners, mother tongue, and education.

Keywords:

(C) 2018 IJERE. All rights reserved

Code mixing, utterances, students of Arab descent, sociolinguistics

\section{INTRODUCTION}

The use of language is inseparable from social relations. Interethnic social relations in the community rise to distinctive linguistic phenomena because they include bilingual or multilingual communities. As a bilingual, Arab descents in Surakarta, Indonesia use several languages to communicate. Surakarta is one of the cities in Indonesia whose population is dominated by Javanese, so that Javanese is the language of the majority of indigenous people in Surakarta. Interethnic interaction results in language contact. If it is found someone who talks by using more than one language, that person is experiencing language contact (Gardner-Chloros, 1991: 108). The language contact event certainly affects the language used by Arab descents living in Surakarta. As a result, Arab descents in Surakarta use more than one language in communication.

The interaction between Arab descents in Surakarta and the indigenous population resulted in language change and language shift. The language used by Arab descents has now experienced a shift from Arabic to Indonesian and Javanese. This is in line with Tseng (2010:383) that language change can occur due to language contact in bilingual communities. The language shift is caused by two factors, namely family factors and group community factors (Coulmas, 2013: 161).

Even though it has undergone a shift, in everyday conversations, Arab descents often insert Arabic in their speech even at the word level. This is a characteristic of the language used by Arab descents so that it can be an identity that they are people of Arab descent. Thus, these peculiarities provide different nuances in the use of language (Maemunah, 2016:48).

The function of using Arabic is to maintain the language of his previous ancestors even though currently it is no longer used as the language of instruction. In addition, the use of Arabic is also part of both individual and social identities. Since, language is able to be identity of certain ethnic as it has different variation (Trudgill, 1975: 59).

Most of the people of Arab descents in Surakarta in everyday life tend to use Indonesian. While Arabic, Javanese, and other foreign languages are only used in certain situations, sometimes they are only used at the word level or what is referred to as code intervening events. Code mixing is the event of the entry of elements of one language into another language (Sumarsono, 2013: 202).

\footnotetext{
${ }^{1}$ Corresponding e-mail: himnindah@gmail.com, orcid.org/0000-0003-3140-3841

Sebelas Maret University ${ }^{1,2,3}$
} 
The events of code-mixing carried out by Arab descents can be found in the realm of education. At school, students of Arab descent naturally interact with students and teachers with fellow ethnic and interethnic groups. In addition, in learning students are required to use formal Indonesian because learning is a formal situation. The transition into formal language which is used in the formal condition occurred when people talk about lesson or knowledge (Treffers-Daller, 1994: 78). While in non-formal situations such as communication outside of learning, Arab descents have a choice of language that matches the situation and speech partners. They often mixed the language with Arabic and Javanese. Besides, they got it from the family, they got Arabic from school. The same happened to Javanese language, the students got Javanese from school as Surakarta is the center of Javanese Culture in Indonesia. Thus, the culture should be integrated in learning (Ardiansyah, Suharno, \& Triyanto, 2018: 48).

Research on code mixing events has been carried out by Sutarsih (2016:175). Sutarsih studied the code mixing in the speech of Arab descents in Pekojan Village, Semarang. The study focused on code mixing and its causes. Then the following year, Sutarsih studied the same thing but with a different study object. In 2018, Sutarsih (2017:163) studied the code mixing event in the Chinese ethnic community utterances in Gang Baru, Semarang. The results of Sutarsih's research are code mixing in the social sphere while this study describes the form of code mixing in the realm of education. The difference between Sutarsih's research in 2016 and 2017 with this research is speech domain. Meanwhile, the research equation of Sutarsih in 2016 and 2017 with this research is that both of them examine code mixing events in bilingual communities of an ethnic group.

Other research on code mixing events was carried out by Heny Kusuma Widyaningrum (2017:49). The study looked at code mixing events of two types, namely in and out code mixing in the form of words, phrases, baster, and clauses. The object in the study is speech in radio broadcaster. The difference between Widyaningrum's research and this research is the speech situation. The speech situation in Widyaningrum's research, namely the non-formal situation in radio broadcaster speech while in this study examines code mixing in formal and non-formal situations in the realm of education. Widyaningrum's research equation with this research is that both examine the intervening events of the code and the contributing factors.

Based on some of the results of the study, it shows that code mixing events can be review ed through various social domains. In bilingual societies, common code mixing events occur. This is influenced by the socio-cultural factors of speakers and speech partners. Therefore, this research raises code mixing events in the realm of education with objects of Arab descent in Surakarta in sociolinguistic reviews. Socio-linguistic studies become a parameter in this study because sociolinguistics studies the relationship between society and language. Thus, the results of the analysis will be obtained showing the language used by students of Arab descent in Surakarta, especially in the event of code mixing. Because, Arab Descent students in Surakarta, Indonesia are bilingual students. The occurrence of code mixing among students becomes the identity of Arab descent in Surakarta as it is found the different language pattern.

\section{METHOD}

This research employed descriptive qualitative method. The data in this research was Arab descent students' utterances at Diponegoro Islamic High School, Surakarta. The utterances were spoken by students of Arabic descents at Diponegoro Islamic High School, Surakarta when interacting in the classroom or outside the classroom. Private Diponegoro Islamic Senior High School students in Surakarta, Indonesia are female aged between 15-18 years old. The objects of this study were students in grade 10-12. The speech involved teachers and students. The data collection techniques in this study used competent involvement techniques. Furthermore, the data analysis was carried out by identifying mixed languages between Indonesian, Javanese, Arabic, and English through functional descriptive analysis. The technique of data validity was member checking to the participants in order to valid the data.

\section{FINDINGS}

This study focused on code mixing events in speech language used by students of Arabic descent at Diponegoro Islamic High School, Surakarta and its contributing factors. The code mixing meant is the 
presence of other language elements, other than Indonesian, such as Arabic, Javanese, and English. The following is the code mixing data uttered by students of Arab descent at Diponegoro Islamic High School, Surakarta, Indonesia.

Speech 1

A : Pertama waktunya sampai sepuluh seperempat, tapi kita ngga mau.

B : Ya iya dong. Masang tenda aja suwe kok.

A : Makanya diperpanjang sampai jam sebelas.

Speech meaning

A : First, the time is until 10.15, but we refused.

B : Yes, it should be. We need more time to put up the tent.

A : That's why they gave extra time.

A and B were Arab students. They weregroup mates in the scout team. A told that the installation time for the tent was extended. In the statement 1 there was a code carried mixing uttered by B, which was a mixture of the Indonesian language with the Javanese language. This could be shown through the word suwe, which means long in English. While A tended to use Indonesian in explaining the statement.

Speech 2

A : Nanti ini dipasangi bendera merah putih, itu saya bahwa bendera merah putih dari rumah.

B : Bu Nur rumahnya kosong ya bu? Kabeh dibaw a ke sini.

Speech meaning

A : This will be fitted with the red and white flag. I bring the red and white flag from home.

B : Mrs Nur's house is empty, isn't Mrs? You bring all your belonging.

A was a teacher accompanying the B scout team. B was a student of Arab descent. The conversation occurred when setting up a gate in front of the tent. The teacher told student B to put the object he was carrying. In the conversation, there w as a code mixing of Indonesian with Javanese which was marked by the use of the word kabeh (Javanese language means all) used by B. The word kabeh means all.

Speech 3

A : Jadi kamu belum ambil rapot?

B : Iya bu. Abiku ngga bisa bu. Nek diambil khalatiku boleh ngga bu?

A : Ya, boleh.

Speech meaning

A : So, you haven't get your report card, have you?

B : Yes, Ma'am. My father couldn't come. If my aunt take the report card, is it ok?

A : Yes, please.

A was the teacher and guardian of the class B. B is a student of Arab descent. A asked B why the report card had not been taken. In the utterances 10, there was a code mixing of Arabic and Javanese languages. The Arabic code mixing was indicated through the word abi and khalati. Abi is Arabic language for father while khalati is Arabic language for aunt from father's line.

Speech 4

A : Kelompok mana yang sudah selesai?

B : Sudah ngirim semalam tapi belum jadi, Bu.

C : Khorot itu Bu

A : Baiklah, tugas video ditayangkan besok saja ya.

B : Siap Bu, yes, Alhamdulillah.

Speech meaning

A : Which group have done?

B : I sent last night but had not done yet.

C : That's a lie, Maam.

A : It's ok. Video assignment will be play tomorrow.

B : Alright, Maam, yes, Alhamdulillah.

A in the speech was the teacher who was teaching in the classroom. B and C were students of Arab descent. In this statement there was a mixed code of Indonesian with Arabic which is carried out by C, namely in the word khorot. Khorot is used to replace lies. In addition, in the speech, the Indonesian language code was mixed with English and Arabic. The English vocabulary that appears is the word yes which is 
based on the word $y a$ in Indonesian while the Arabic vocabulary that appears is Alhamdulillah as a thanksgiving.

Speech 5

A : Kerjaanmu nanti ana share ya sama temen-temen.

B : Ojo ndak halal.

A : Wes to ndakpapa.

B : Ndak ndak.

A : Ya wis aku rejak sik ya.

B : Hati-hati.

Speech meaning

A : I will distribute your work to our friends.

B : Don't do that, that's not good.

A : It's okay.

B : Please, don't.

A : Alright, I go home first.

B : Be Careful.

A and B were students of Arab descent who were chatting before the school gate. In utterance 14, there was a code mixing event between Indonesian and Arabic and English. This was indicated by the word ana and share. Ana is the first person in Arabic. Ana has the equivalent of I or me in English. In addition, there was the word rejak in the utterances which means to go home. Meanwhile, mixed code between Indonesian and Javanese was shown through the use of the word wis and sik, which included in the Javanese Language. Speech 6

A : : Apapun yang masuk ke dalam tubuh membatalkan salat, paham?

B : Paham. Kalau keleleken peniti gimana us?

A : Ya batal.

Speech meaning

A : Everything that enter into body repeals prayer, understand?

B : Understand. How if swallow a pin, Ma'am?

A : It canceled.

A was a teacher of Arab descent. In the speech, A used formal Indonesian language because learning activities were formal situations. B was a student of Arab descent. In the speech, the Indonesian language code was mixed with the Javanese language. The use of Javanese was found in the word keleleken which means swallowed.

Speech 7

$\begin{array}{ll}\text { A } & \text { : Fatimah } \\ \text { B } & \text { : Labbaik, kenapa Han? } \\ \text { A } & \text { : Hey ini hlo the head master of kimia. } \\ \text { Speech meaning }\end{array}$

A : Fatimah

B : I fulfill your call, why Han?

A : Hey, this is the head master of chemistry.

A and B were Arab students. In this speech, A called the name of B. Labbaik including the Arabic code used by B to answer the call from A. Labbaik means 'I fulfill your call'. In B's utterance there is the word 'the head master' of which is a phrase in English.

\section{RESULT AND DISCUSSION}

The existence of code-mixing events, in line with a statement that the problem that arises in ethnic minorities is the dilemma of choosing language in education, whether to continue to use mother ton gue or switch to the language of the majority (Chaklader, 1990: 281). Based on the data, it can be seen the code mixing event occurred in the utterances of students of Arab descent at Diponegoro Islamic High School, Surakarta. The code mixing is a mixture of Indonesian with Javanese, Arabic and English. In non-formal situations students of Arab descent tended to choose mixed languages so that code mixing events could not 
be avoided. This meant that communication seemed familiar because it occurred between students who were still in their teens. While in communicating with teachers, students tended to choose formal Indonesian. The form of mixed code carried out by students of Arab descent in non-formal situations in a relaxed and familiar atmosphere. This is in line with the results of Yulianti's research (2015) which states that code mixing can occur due to relaxed situations and become the habit of speakers in an unofficial situation.

The cause of the mixed code between Indonesian and Javanese is the language majority. The language majority used by indigenous people in Surakarta is Javanese. Therefore, as part of the Surakarta community, Arab descents naturally interact with the people of Javanese descent. Thus, the speech partner influences the occurrence of mixed code which results in Arab descents inserting Javanese. Likewise with students of Arab descent who interact with students of Javanese descent. This interaction causes students of Arab descent to be accustomed to using Javanese even though only at words and phrases. In addition, some teachers who interact with students of Arab descent at Diponegoro Islamic High School are Javanese descent so students of Arab descent are accustomed to using Javanese.

Basically, Javanese language has several speech levels which appropriate with any social situation, that are ngoko and krama. Ngoko is used in the familiar situation and is used to talk with people from lower level. Ngoko can be said as rude speech level. While krama is used to talk with people from higher social status and not familiar yet. Based on these data, students of Arab descent can only use Javanese ngoko (the lowest level in Javanese Language) both when interacting with fellow students and with teachers. This is due to lack of Javanese understanding. Necessarily, when students talk to their teacher, students use krama Javanese. Since, Krama Javanese is used to talk with speech partner whose higher level of social status.

Meanwhile, the cause of the code mixing between Indonesian and Arabic is a factor in the background of the mother tongue of former Arab descents. In the realm of family, there are still some Arab descents who speak Arabic to communicate. The code mixing between Indonesian and Arabic is only found at the word level. Students of Arab descent mix Indonesian and Arabic when communicating with fellow Arab descent. Even so, sometimes Arab descents mix code in Arabic if the speech partner can understand Arabic.

Mixing the Indonesian language code with English was done by students of Arabic descent at words and phrases. This is in accordance with the theory proposed by Ager (1990: 7) which states that mixed language in the form of words, phrases and sentences from one language to another is part of the evidence of contact between languages. The code mixing $w$ as done when having a conversation with fellow students. The factor that led to the mixing of the code was education. As students who are taking secondary school, they can use English even at the lowest level, ad English is a foreign language that must be studied from elementary to tertiary level. Based on the analysis result, it is suggested for the other researchers to do the same research comprehensively by studying the language used by Arab descent in school environment, from elementary until university. Thus, the different result will be achieved.

\section{CONCLUSION}

Based on the results of the analysis in this study, it can be concluded that students of Arab descent at the Diponegoro Islamic High School Surakarta, Indonesia mixed code from Arabic, Javanese, and English into Indonesian. This code mixing event forms a distinctive language pattern as an Arab descent. The code mixing carried out by students of Arab descent in the Diponegoro Islamic High School Surakarta, Indonesia is influenced by several factors including language majority, speech partners, mother tongue, and education.

\section{REFERENCES}

Ager, D. E. (1990). Sociolinguistics and Contemporary French. Cambridge: Cambridge University Press.

Ardiansyah, R., Suharno, \& Triyanto. (2018). Inheritance national culture through learning in elementary school at disruptive era: Case study in Surakarta Indonesia. International Journal of Educational Research Review, 3(4), 48-53.

Bell, A. (2013). The Guidebook to sociolinguistics. UK: John Wiley \& Sons.

Chaklader, S. (1990). Sociolinguistics: A Guide to Language Problems in India. India: Mittal Publications. 
Nur'aini, H.I.M., Slamet,S.Y. \& Setiawan,B. (2019). Code mixing used in the utterances of Arab descent students in Surakarta,

Indonesia (Sociolinguistics study). International Journal of Educational Research Review,4(1),50-55.

Coulmas, F. (2013). Sociolinguistics: The study of speakers' choices. Cambridge: Cambridge University Press.

Fought, C. (2006). Language and ethnicity. New York: Cambridge University Press.

Maemunah, E. (2017). Penggunaan Bahasa Mahasiswa Multietnik dalam Media Sosial. Jalabahasa, 12(1), 4758.

Rokhman. F. (2013). Sosiolinguistik: Suatu Pendekatan Pembelajaran Bahasa dalam Masyarakat Multikultural. Semarang: Graha Ilmu.

Saddhono, K. (2013). Pengantar Sosiolinguistik Teori dan Konsep Dasar. Surakarta: Sebelas Maret University Press.

Sumarsono. (2013). Sosiolinguistik. Yogyakarta: Pustaka Pelajar.

Sutarsih, A. (2016). Campur Kode dari Bahasa ke dalam Bahasa Indonesia Tuturan Masyarakat Keturunan Arab di Kampung Pekojan Semarang. Widyaparwa, 44(2), 175-183.

Sutarsih. (2017). Campur Kode dalam Pertuturan Masyarakat Etnik Cina di Gang Baru Semarang (Code Mixing in the Utterances of Chinese Ethnic Community in Gang Baru Semarang). Sawerigading, 23(2), 163-172.

Tagliamonte, S. (2012). Variationist sociolinguistics: Change, observation, interpretation. Southern Gate: John Wiley \& Sons.

Tseng, S. C. (2016). /kwo/and/y/in Taiwan Mandarin: Social Factors and Phonetic Variation. Language and Linguistics, 17(3), 383-405.

Widyanigrum, H. K. (2018). Campur Kode Siaran Radio Most FM Penyiar Ari di Kota Malang. Kembara, 3(1), 49-54.

Yulianti, A. I. (2015). Campur Kode Bahasa Dayak Ngaju dan Bahasa Indonesia pada Kicauan Twitter Remaja di Palangkaraya. Kandai, 11(1), 15-28. 